\title{
PENGEMBANGAN UKBM DENGAN PENDEKATAN ENGINEERING DESIGN PROCESS (EDP) UNTUK MENINGKATKAN LITERASI STEM SISWA SMA
}

\author{
${ }^{1)}$ Indri Widiyanti ${ }^{1)}$ Pramudya Dwi Aristya Putra ${ }^{1)}$ Firdha Kusuma Ayu Anggraeni \\ ${ }^{1)}$ Program Studi Pendidikan Fisika FKIP Universitas Jember \\ E-mail: widiyantiindri0@gmail.com
}

\begin{abstract}
UKBM is a learning tool using the Semester Credit System (SKS) and is a small learning unit that is arranged sequentially by involving study time units. This research was focused on developing UKBM with the Engineering Design Process (EDP) approach in learning physics in senior high school. The purpose of this research was to produce a valid UKBM and to determine the effectiveness of UKBM through increasing students' STEM literacy after using the EDP-based UKBM. The type of this research was a research and development $(R \& D)$ model with the ADDIE model consisting of five stages, namely: Analysis, Design, Development, Implementation and Evaluation. The results of the validity of product development are declared valid by the three validators with an average percentage of $88 \%$, so that product development can be implemented in schools. The results of the effectiveness obtained from analyzing the results of the pre-test and post-test $N$-gain with the acquisition of $N$-Gain of $76.96 \%$ so that it is in the high category. The development of UKBM with the Engineering Design Process (EDP) Approach to improve STEM literacy of high school students was declared valid and effective.
\end{abstract}

Key word: Engineering Design Process, STEM Literacy, UKBM

\section{PENDAHULUAN}

Fisika menurut Prasetyo (dalam Harefa, 2019) adalah ilmu pengetahuan alam dapat dinyatakan sebagai kumpulan pengetahuan yang merupakan sebuah penemuan dari suatu kegiatan kreatif, cara berpikir serta cara penyelidikan yaitu ilmu yang memberikan ilustrasi mengenai pendekatan-pendekatan untuk menyusun suatu pengetahuan. Menurut Giancoli (2001) Fisika merupakan ilmu tentang alam yang tidak hidup ataupun sifat materi pada bidang yang beragam mulai dari materi yang terbentuk dari berbagai partikel submikroskopis hingga perilaku alam semesta sebagai kesatuan kosmos.

Menurut Trianto (dalam Kusuma, 2015: 336-337) terjadi hambatan-hambatan yang dihadapi dalam proses pembelajaran, seperti model pembelajaran yang belum sesuai dengan kondisi siswa, media pembelajaran yang kurang efektif dalam proses pembelajaran, dan kondisi kelas yang cenderung hanya berpusat pada guru. Siswa hanya diarahkan sebatas menghafalkan teori dan rumus saja dan kurang melibatkan permasalahan di kehidupan sehari-hari.

Adanya hambatan yang dihadapi dalam proses pembelajaran mengakibatkan terjadi miskonsepsi. Salah satu materi yang 
sering mengalami miskonsepsi adalah rangkaian arus bolak-balik (AC) dikarenakan materi tersebut banyak melibatkan permasalahan di kehidupan sehari-hari. Hal ini didukung dengan penelitian oleh Agustin R D (2018:141) mengatakan bahwa siswa mengalami kesulitan dan kesalahan dalam memecahkan permasalahan pada materi arus bolak-balik. Sedangkan penelitian yang dilakukan oleh penelitian yang dilakukan Nugraeni (2013) mengidentifikasi terdapat $42 \%$ siswa mengalami miskonsepsi, $16 \%$ tidak paham konsep dan $42 \%$ siswa memahami konsep pada penerapan arus bolak-balik (AC).

Hasil wawancara dengan guru SMA Negeri 1 Kejayan mengatakan bahwa bahan ajar yang dibuat hanya berisi soal-soal matematis dan konsep tanpa melibatkan aplikasinya dalam kehidupan sehari-hari sehingga terjadi hambatan pada proses pembelajaran. Oleh karena itu, salah satu solusi alternatif untuk permasalahan yang sudah diapaprkan adalah perlu adanya pengenalan pembelajaran Engineering design Process (EDP).

Menurut Wind Stefani et al, 2019:4, Engineering Design Process (EDP) merupakan proses pembelajaran yang mengenalkan pembelajaran teknik kepada siswa. Siswa dilatihkan untuk mampu menganalisis permasalahan nyata melalui pengetahuan yang sudah diperoleh serta memberikan solusi dari permasalahan dalam bentuk produk. Engineering Design Process bertujuan untuk memberikan peluang kepada siswa untuk mengembangkan dan menerapkan aplikasi konsep fisika (Berland et al., 2014).

Pendekatan Engineering Design Process dalam proses pembelajaran dapat menciptakan aktivitas baru yang mengajarkan desain teknik pada siswa, sehingga melibatkan siswa untuk meningkatkan literasi STEM (Science, Technology, Engineering and Mathmatics).
Menurut Tati (2017:2), literasi STEM merupakan kemampuan mengidentifikasi, mengaplikasikan dan mengintegrasikan konsep dari science, technology, engineering and mathematics dari suatu permasalahan yang kompleks serta memiliki pengetahuan dan keterampilan kreatif untuk menyelesaikannya.

Meningkatkan literasi STEM pada siswa perlu adanya pembaruan terhadap kurikulum, teknologi dan proses pembelajaran yang efektif, salah satunya adalah merancang Unit Kegiatan Belajar Mandiri (UKBM). Unit Kegiatan Belajar Mandiri merupakan perangkat pembelajaran dengan menggunakan Sistem Kredit Semester (SKS) dan merupakan satuan pembelajaran kecil yang disusun secara berurutan dengan melibatkan satuan waktu (Direktorat Pembinaan SMA, 2017:5)

Penelitian Fajriyah (dalam Majid \& Linuwih, 2019:229) mengatakan bahwa penggunaan UKBM di beberapa sekolah di Jawa Timur, masih belum efektif karena kurangnya petunjuk secara tertulis maupun penekanan dari guru dan tampilan yang kurang menarik sehingga menyebabkan kurang efektivitasnya UKBM maka peneliti akan melakukan pengembangan UKBM. Tujuan dari penelitian ini adalah untuk mengkaji validitas UKBM dan menganalisis efektivitas UKBM melalui peningkatan literasi STEM.

\section{METODE}

Jenis penelitian ini merupakan penelitian pengembangan (Research \& Development). Penelitian dilakukan di SMA Negeri 1 Kejayan yang ditentukan menggunakan metode purposive sampling dengan subjek uji pengembangan siswa semester 5 dengan 1 kelas uji pengembangan. Teknik pengumpulan data pada penelitian ini adalah wawancara, lembar angket, validasi ahli dan tes. Desain penelitian menggunakan model ADDIE oleh 
Dick and Carry yang terdiri dari 5 tahap pengembangan, yaitu: Analysis, Design, Development, Implementation dan Evaluation.

Pada penelitian ini teknik analisis data diperoleh dari validasi UKBM berbasis Engineering Design Process (EDP) yang dilakukan oleh dua validator ahli. Data skor yang diperoleh dari validator dikonversi dalam bentuk persentase menggunakan rumus :

$P(\%)=\frac{f}{N} x 100$

Sudijono (2009:43)

Selanjutnya data hasil perhitungan diklasifikasikan berdasarkan kriteria yang tercantum pada Tabel 1 berikut.

Tabel 1. Kriteria Validitas Ahli

\begin{tabular}{|l|l|l|}
\hline No & Presentase & Interprestasi \\
\hline 1 & $81 \%-100 \%$ & Sangat valid \\
\hline 2 & $61 \%-80 \%$ & Valid \\
\hline 3 & $41 \%-60 \%$ & Cukup Valid \\
\hline 4 & $21 \%-40 \%$ & Tidak Valid \\
\hline 5 & $0 \%-20 \%$ & Sangat Tidak Valid \\
\hline
\end{tabular}

(Sudaryono, 2011:36)

Selain itu, teknik analisis data juga diperoleh dari efektivitas UKBM berbasis Engineering Design Process (EDP). Pada penelitian ini pengujian efektivitas diukur dari peningkatan hasil literasi STEM (science, technology, engineering and mathematics) yang didapatkan dari dari hasil pre-test dan post-test. Selanjutnya hasil pre-test dan posttest dianalisis menggunakan $\mathrm{N}$-gain score dengan rumus

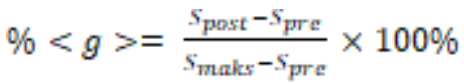

Hake \& Ricard (2002)
Setelah data dianalisis dengan $\mathrm{N}$-gain score, data hasil perhitungan diklasifikasikan berdasarkan kriteria yang tercantum pada Tabel 2.

Tabel 2. Kriteria N-Gain

\begin{tabular}{|l|l|}
\hline Klasifikasi Nilai $<\mathrm{g}>$ & Kriteria \\
\hline $\boldsymbol{g} \geq \mathbf{7 0} \%$ & Tinggi \\
\hline $\mathbf{3 0} \% \leq \boldsymbol{g}<\mathbf{7 0} \%$ & Sedang \\
\hline $\boldsymbol{g}<\mathbf{3 0} \%$ & Rendah \\
\hline
\end{tabular}

(Simanjutak, 2012:5)

\section{HASIL DAN PEMBAHASAN}

1. Validitas Produk UKBM dengan pendekatan Engineering Design Process (EDP) divalidasi oleh 3 validator. Instrumen pengukuran untuk validasi UKBM dengan pendekatan Engineering Design process (EDP) terdiri dari 20 indikator yang dikelompokkan menjadi 4 aspek yaitu aspek isi, aspek bahasa, aspek penyajian dan aspek kegrafikan.

Aspek isi terdiri dari 7 indikator, yaitu kesesuaian bahan ajar dengan Kompetensi Inti dan Kompetensi Dasar, tujuan pembelajaran, kebutuhan siswa, integrasi materi dengan Engineering Design process (EDP), meningkatnya literasi STEM, langkah-langkah pembelajaran K-13 dan kejelasan petunjuk. Aspek bahasa terdiri dari 5 indikator yaitu aspek keterbacaan, kejelasan informasi dan arahan, bahasa efektif dan efisien, kaidah bahasa Indonesia, dan sifat komunikatif. Aspek penyajian terdiri dari 5 indikator yaitu bahan ajar disajikan menarik, disajikan secara runtut, memiliki kelengkapan informasi, mudah dipahami siswa, memberikan motivasi. Aspek kegrafikan memiliki 3 indikator yaitu penggunaan font, layout tata letak dan desain tampilan. Hasil validasi UKBM dengan Pendekatan Engineering Design Process (EDP) dapat dilihat pada Tabel 3. 
Tabel 3. Tabel Hasil Validasi UKBM dengan Pendekatan Engineering Design Process (EDP)

\begin{tabular}{lcccc}
\hline Aspek & $\begin{array}{c}\text { Rata- } \\
\text { Rata } \\
\text { Aspek }\end{array}$ & $\begin{array}{c}\text { Total } \\
\text { Rata- } \\
\text { Rata } \\
\text { Aspek }\end{array}$ & Persentase & $\begin{array}{c}\text { Tingkat } \\
\text { Validitas }\end{array}$ \\
\cline { 1 - 2 } Aspek isi & 4,38 & & & \\
\cline { 1 - 2 } Aspek & 4,53 & & & \\
Bahasa & 4,38 & $88 \%$ & $\begin{array}{c}\text { Sangat } \\
\text { Valid }\end{array}$ \\
$\begin{array}{l}\text { Aspek } \\
\text { Penyajian }\end{array}$ & 4,27 & & & \\
\cline { 1 - 2 } $\begin{array}{l}\text { Aspek } \\
\text { Kegrafikan }\end{array}$ & 4,33 & & & \\
\hline
\end{tabular}

Hasil rata-rata keempat aspek yang diperoleh dari 2 validator ahli dan 1 validator pengguna sebesar 4,38. Perolehan skor rata-rata dari keempat aspek akan dikonversikan dalam bentuk persentase sehingga diperoleh persentase sebesar $88 \%$ yang artinya bahwa produk UKBM dengan pendekatan Engineering Design Process (EDP) dikategorikan sangat valid. Dari hasil persentase yang diperoleh maka UKBM dengan pendekatan Engineering Design Process (EDP) dinyatakan layak digunakan dan dapat diimplementasikan ke tempat uji pengembangan.

2. Efektivitas Produk

Efektivitas UKBM dengan pendekatan Engineering Design Process (EDP) dianalisis menggunakan analisis deskriptif kuantitatif menggunakan uji $\mathrm{N}$-gain untuk mengetahui efektivitas bahan ajar yang dikembangkan dalam meningkatkan literasi STEM (Science, Technology, Engineering and Mathematics). Uji N-gain dapat diperoleh dengan menganalisis total rata-rata indikator pada pre-test dan post-test.

Menurut National Academy Of Science (dalam Aninda A et al 2019:9) literasi STEM (Science, Technology, Engineering and Mathematics) terdiri dari 8 indikator yaitu: mengajukan pertanyaan dan mendefinisikan masalah; mengembangkan dan menggunakan model; merencanakan dan melakukan investigasi; menganalisis dan menafsirkan data; menggunakan matematika, teknologi informasi dan komputer, dan berpikir komputasi; membangun eksplanasi (science) dan merancang solusi (engineering); terlibat dalam argumentasi berdasarkan bukti; memperoleh, mengevaluasi dan mengkomunikasikan informasi. Hasil peningkatan tiap indikator pre-test dan posttest pada Uji N-gain dapat dilihat Gambar 1.

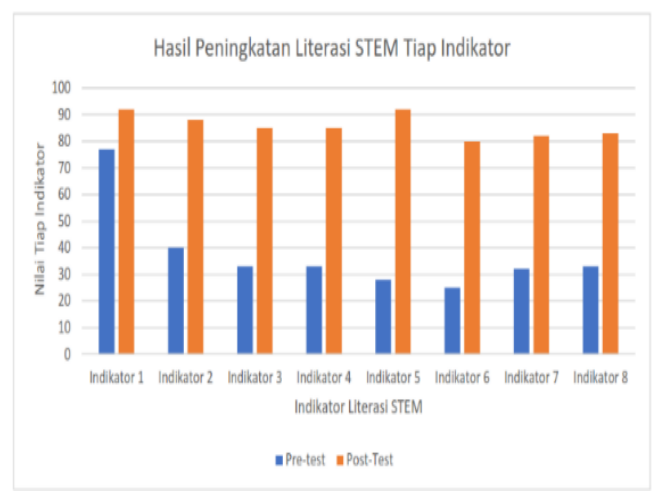

Gambar 1. Grafik Hasil Peningkatan Literasi STEM Tiap Indikator

Indikator pertama literasi STEM adalah mengajukan pertanyaan dan mendefinisikan masalah. Pada indikator pertama siswa dapat mendefinisikan masalah dari permasalahan yang telah dipaparkan dalam soal. Pada uji lapangan, indikator pertama dikategorikan sedang dengan persentase uji N-gain sebesar $65 \%$. Hasil uji N-gain dapat disimpulkan bahwa terjadi peningkatan pada indikator pertama yaitu mengajukan pertanyaan dan mendefinisikan masalah.

Indikator kedua literasi STEM adalah membangun eksplanasi (science) dan merancang solusi (engineering). Pada indikator kedua, siswa dapat memuat informasi berdasarkan fakta yang berisi informasi bersifat keilmuan serta memberikan solusi dari permasalahan yang telah dipaparkan dalam soal. Indikator kedua dikategorikan tinggi baik dengan persentase uji $\mathrm{N}$-gain sebesar $80 \%$. Hasil uji $\mathrm{N}$-gain 
dapat disimpulkan bahwa terjadi peningkatan pada indikator kedua yaitu membangun eksplanasi (science) dan merancang solusi (engineering).

Indikator ketiga literasi STEM adalah Menggunakan matematika, teknologi informasi dan komputer dan berpikir komputasi. Pada indikator ketiga, siswa berpikir komputasi dengan cara mendesain atau merancang alat dimana siswa menggunakan kemampuannya menghasilkan teknologi baru dengan ukuran dan komposisi bahan yang digunakan (Aninda $\mathrm{A}$ et al 2019:9). Pada proses mendesain dapat memotivasi siswa untuk mempelajari matematika dan konsep science yang memungkinkan terciptanya teknologi baru (Stohlmann, 2012). Indikator ketiga dikategorikan tinggi dengan persentase uji $\mathrm{N}$-gain sebesar $78 \%$. Hasil uji $\mathrm{N}$-gain dapat disimpulkan bahwa terjadi peningkatan pada indikator ketiga yaitu mengembangkan dan menggunakan model.

Indikator keempat literasi STEM adalah mengembangkan dan menggunakan model. Pada indikator keempat, siswa dapat medesain, merancang atau mengembangkat sketsa atau design rekayasa dari solusi permasalahan. Indikator keempat dikategorikan tinggi baik dengan persentase uji $\mathrm{N}$-gain sebesar $78 \%$. Hasil uji $\mathrm{N}$-gain dapat disimpulkan bahwa terjadi peningkatan pada indikator keempat yaitu mengembangkan dan menggunakan model.

Indikator kelima literasi STEM adalah merencanakan dan melakukan investigasi. Pada indikator kelima, siswa dapat merencanakan dan melakukan investigasi dari sketsa hasil solusi yang telah dibuat dengan merencanakan alat dan bahan yang akan digunakan untuk menyelesaikan solusi. Indikator kelima dikategorikan tinggi, dengan persentase uji N-gain sebesar $89 \%$. Hasil uji N-gain dapat disimpulkan bahwa terjadi peningkatan pada indikator kelima yaitu merencanakan dan melakukan investigasi.

Indikator keenam literasi STEM adalah memperoleh, mengevaluasi dan mengkomunikasikan informasi. Pada indikator keenam, siswa dapat mengkomunikasikan hasil solusi, sketsa dan rencana pembuatan sesuai dengan konsep materi. Indikator keenam dikategorikan tinggi dengan persentase uji $\mathrm{N}$-gain sebesar 73\%. Hasil uji N-gain dapat disimpulkan bahwa terjadi peningkatan pada indikator keenam yaitu memperoleh, mengevaluasi dan mengkomunikasikan informasi.

Indikator ketujuh literasi STEM yaitu terlibat argumentasi berdasarkan bukti. Pada indikator ketujuh, siswa dapat berargumen dengan memberikan penjelasan konsep yang digunakan untuk memperkuat solusi yang diberikan dengan benar. Indikator ketujuh dikategorikan tinggi, baik pada uji terbatas maupun uji lapangan. Pada uji terbatas selisih pre-test dan post-test sebesar 57 dengan persentase uji $\mathrm{N}$-gain sebesar $74 \%$. Sedangkan pada uji lapangan, selisih pretest dan post-test 50 dengan persentase uji $\mathrm{N}$-gain sebesar $74 \%$. Hasil uji $\mathrm{N}$-gain dapat disimpulkan bahwa terjadi peningkatan pada indikator ketujuh yaitu terlibat argumentasi berdasarkan bukti.

Indikator kedelapan literasi STEM yaitu menganalisis dan menafsirkan data. Pada indikator kedelapan, siswa dapat menganalisis dan menafsirkan data dari soal yang dipaparkan sehingga mendapatkan hasil yang sesuai. Indikator kedelapan dikategorikan tinggi, baik pada uji terbatas maupun uji lapangan. Pada uji terbatas selisih pre-test dan post-test sebesar 37 dengan persentase uji $\mathrm{N}$-gain sebesar $74 \%$. Sedangkan pada uji lapangan, selisih pretest dan post-test 50 dengan persentase uji $\mathrm{N}$-gain sebesar $75 \%$, sehingga dapat disimpulkan terjadi peningkatan.

Berdasarkan hasil analisis menggunakan $\mathrm{N}$-gain score menunjukkan 
bahwa terjadi peningkatan literasi STEM siswa yang dilihat dari perbedaan hasil ratarata pre-test dan post-test. Mengacu pada kriteria Normalized gain menunjukkan bahwa peningkatan literasi STEM pada siswa berada pada kategori tinggi dengan perolehan N-Gain sebesar $76.96 \%$. Oleh karena itu dapat dinyatakan bahwa UKBM dengan pendekatan Engineering Design process (EDP) pokok bahasan rangkaian arus bolak-balik dapat dinyatakan efektif untuk meningkatkan literasi STEM siswa.

\section{SIMPULAN DAN SARAN}

Kesimpulan pada penelitian Pengembangan UKBM dengan Pendekatan Engineering Design Process (EDP) antara lain: (1) UKBM Dengan Pendekatan Engineering Design Process (EDP) dikategorikan sanga valid oleh validator ahli dan validator pengguna dengan perolehan skor rata-rata 4,38 dan persentase kevalidan $88 \%$, sehingga produk dapat diimplementasikan pada tempat uji pengembangan, dan (2) UKBM Dengan Pendekatan Engineering Design Process (EDP) dikategorikan efektif dalam meningkatkan literasi STEM siswa SMA dengan perolehan skor rata-rata $77.41 \%$ Skor rata-rata uji $\mathrm{N}$-gain yang diperoleh dikategorikan tinggi.

\section{DAFTAR PUSTAKA}

Agustin, R. D., A. Harijanto, dan S. H. B Prastowo. (2018). Identifikasi Miskonsepsi Siswa Pada Materi Rangkaian Arus Bolak-Balik Menggunakan Four-Tier Test Di SMA. Jurnal Pembelajaran Fisika. 7(2):141-146

Aninda, A., A. Permanasari, dan D.

Ardianto. 2019. Implementasi Pembelajaran Berbasis Proyek Pada Materi Pencemaran Lingkungan Untuk Meningkatkan Literasi STEM Siswa
SMA. Journal Of Science Education and Practice. 3(2):1-16

Berland, L., R. Steingut, dan P. Ko. 2014.

High School Student Perceptions Of The Utility of The Engineering Design Process: Creating Opportunities to Engage In Engineering Practices And Apply Math And Science Content. Journal of Science Education and Technology. 23(6): 705-720

Giancoli, Douglas C. 2001. Fisika Jilid 2

Edisi Kelima. Jakarta: Erlangga

Harefah, A R. 2019. Peran Ilmu Fisika

Dalam Kehidupan Sehari-hari. Jurnal Warta. 60

Kementrian Pendidikan dan Kebudayaan

Republik Indonesia. 2017. Panduan Pengembangan Unit Kegiatan Belajar Mandiri (UKBM). Jakarta Direktorat Jenderal Pendidikan Dasar dan Menengah. Bagian Pembinaan Sekolah Menengah Atas.

Kusuma, T.A., Indrawati, dan A. Harijanto.

2015. Model Discovery Learning Disertai Teknik Probing Prompting Dalam Pembelajaran Fisika Di MA. Jurnal Pendidikan Fisika. 3(4): 336-341

Majid M. I., dan L. Suharto . 2019.

Pengembangan Unit Kegiatan Belajar Mandiri (UKBM) Materi Usaha dan Energi Berbasis Pembelajaran Kontekstual Untuk Meningkatkan Pemahaman Konsep Siswa. Unnes Physics Education Journal. 8(3): 228238

Simanjutak, M. P. 2012. Peningkatan

Pemahaman Konsep Fisika Mahasiswa Melalui Pendekatan Pembelajaran Pemecahan Masalah Berbasis Video. Jurnal Pendidikan Fisika. 1(2): 55-60

Sudaryono., S. Guritno, dan U. Raharjo.

2011. Theory and Application of IT Research: Metodologi Penelitian Teknologi Informasi. Yogyakarta: Andi Offset

Wind, A. S., M. Alemdar, J.A Lingle, M. 
Roxanne dan Asilkalkan A. 2019. Exploring Student Understanding Of The Engineering Design Process Using Distraktor Analysis. International Journal of STEM Education. 6(4) 